\title{
PENGARUH PENGGUNAAN METANOL BEKAS PAKAI SECARA BERULANG-ULANG TERHADAP RENDEMEN DAN MUTU BIODIESEL DENGAN BANTUAN REAKTOR KAVITASI HIDRODINAMIK
}

\section{The Using Effect of Repeatedly Used Methanol Toward Yield and Quality of Biodiesel Assisted by Hydrodinamic Cavitation Reactor}

Mahlinda* dan Lancy Maurina

Balai Riset dan Standardisasi Industri Banda Aceh

Jl. Cut Nyak Dhien No. 377 Lamteuemen Timur Banda Aceh 23236

*E-mail: mahlinibr_aceh@yahoo.com

\begin{abstract}
ABSTRAK
Penelitian tentang pengaruh penggunaan metanol bekas pakai secara berulang-ulang terhadap rendemen dan mutu biodiesel menggunakan reaktor kavitasi hidrodinamik telah dilaksanakan. Tujuan dari penelitian ini adalah untuk mempelajari pengaruh penggunaan metanol bekas pakai yang dipakai secara berulang-ulang dengan mengamati rendemen dan mutu biodiesel yang dihasilkan. Variabel konstan yang digunakan pada proses transesterifikasi ini adalah rasio molar metanol dan minyak $4: 1$, katalis $\mathrm{KOH} 1 \%$, temperatur $45^{\circ} \mathrm{C}$ dan waktu reaksi 60 menit. Variabel berubah adalah jumlah ulangan penggunaan metanol terdiri dari 4 ulangan (ulangan 1 menggunakan metanol baru dan 3 ulangan mengggunakan metanol bekas). Hasil penelitian menunjukkan bahwa produk biodiesel yang dihasilkan tidak dapat digunakan secara langsung di mesin diesel karena beberapa parameter yang diuji tidak memenuhi persyaratan SNI 04-7182:2006.
\end{abstract}

\section{Kata Kunci: Biodiesel, transesterifikasi, metanol bekas pakai, kavitasi hidrodinamik}

\section{ABSTRACT}

Research on the using effect of repeatedly used methanol toward yield and quality of biodiesel assisted by hydrodinamic cavitation reactor had been done. The aim of this research was to study the effect of used methanol which is used repeatedly toward yield and quality of biodiesel products. The constant variable used in the transesterification process was the molar ratio of methanol and oil $4: 1, \mathrm{KOH}$ catalyst $1 \%$, temperature $45^{\circ} \mathrm{C}$ and reaction time 60 minutes. The manipulated variable was the number of used methanol replications consisted of 4 replications (replication 1 using fresh methanol and 3 replications using used methanol). The results of the research showed that biodiesel products could not be used directly in diesel engines because some parameters that were tested did not meet the requirements of SNI 04-7182:2006.

Keywords: Biodiesel, transesterification, used methanol, hydrodinamic cavitation 


\section{PENDAHULUAN}

Meningkatnya permintaan akan minyak bumi seperti solar diseluruh dunia akan berdampak pada pasokan minyak dunia dimana saat ini pasokan minyak dunia semakin menipis. Saat ini porsi utama dari total energi yang dikonsumsi bersumber dari bahan bakar berbasis fosil yang tidak dapat diperbaharui dan akan habis di masa depan. Untuk mengatasi kendala tersebut, para peneliti berupaya mencari sumber-sumber energi baru yang dapat diperbaharui salah satunya adalah penggunaan biodiesel sebagai pengganti bahan bakar solar. Biodiesel diproduksi melalui suatu reaksi kimia yang dikenal dengan sebutan transesterifikasi. Pada proses transesterifikasi, minyak nabati atau hewani direaksikan dengan bantuan katalis menggunakan pelarut sejenis alkohol dalam jumlah tertentu untuk merubah asam lemak bebas dan trigliserida dalam minyak tersebut menjadi metil ester (biodiesel) dan gliserol sebagai produk sampingan (Canakci and Gerpen, 2001., Hambali dkk, 2006). Biodiesel adalah metil ester turunan dari minyak lemak alami, seperti minyak nabati atau lemak hewan yang dapat digunakan langsung atau dicampur dengan minyak diesel. Keuntungan penggunaan biodiesel sebagai bahan bakar diantaranya adalah: bahan baku dapat diperbarui (renewable), dapat menggantikan bahan bakar diesel tanpa perlu melakukan modifikasi mesin, dapat mengurangi emisi yang menyebabkan pemanasan global, dapat mengurangi emisi udara beracun, bersifat biodegradable serta mudah digunakan (Sahirman et al, 2008., Lee et al, 2011).

Proses produksi biodiesel dilakukan dengan cara mencampur minyak nabati atau hewani dengan sejumlah pelarut seperti metanol dan katalis yang disebut dengan proses transesterifikasi. Metanol lebih banyak digunakan sebagai sumber alkohol karena rantainya lebih pendek, lebih polar dan harganya lebih murah dari alkohol lainnya. Metanol yang digunakan dalam proses transesterifikasi biasanya dalam jumlah yang berlebih untuk memicu reaksi pembentukan produk ( $\mathrm{Ma}$ and Hanna, 1999). Penggunaan metanol dalam jumlah besar pada proses sistesa biodiesel akan menimbulkan masalah dikemudian hari seperti meningkatnya biaya produksi untuk pembelian metanol, menghasilkan limbah buangan yang akan menimbulkan pencemaran lingkungan, mudah terjadinya kebakaran, kesulitan dalam transportasi dan penyimpanan serta akan menimbulkan dampak negatif terhadap kesehatan manusia karena metanol bersifat racun (Dhar and Kirtania,. 2009). Untuk memenuhi persayaratan mutu ASTM D6751, sisa metanol dalam biodiesel harus dipisahkan dan dimurnikan (recovery) untuk digunakan kembali karena hampir semua standar yang ada hanya mengizinkan $0,2 \%$ metanol dalam produk akhir (Gerpen and Knothe, 2005).

Kavitasi merupakan suatu fenomena perubahan fase uap dari zat cair pada fluida yang mengalir ketika melewati sebuah lobang yang sempit seperti venturi atau orifice. Ketika fluida pada kecepatan tertentu, tekanan fluida akan lebih kecil dari tekanan uapnya sehingga fluida akan berubah fase membentuk sejumlah gelembung kavitasi. Gelembunggelembung kavitasi ini akan terus tumbuh dan kemudian menghilang ketika tekanan fluida kembali normal setelah fluida melewati orifice. (Moholkar et al, 1999). Dalam studinya, Ji et al. (2006) dan Kelkar et al. (2008) melaporkan penggunaan teknik kavitasi hidrodinamik untuk memproduksi biodiesel terbukti dapat mempercepat reaksi, mengurangi jumlah katalis yang dipakai dan mengurangi rasio minyak terhadap alkohol yang dipakai serta konsumsi energi yang lebih kecil dibandingkan proses menggunakan pengaduk mekanik.

Penelitian tentang penggunaan metanol bekas pakai baik pada proses transesterifikasi konvensional maupun in situ masih jarang dilakukan yang dapat dilihat dengan minimnya publikasi di jurnal nasional bahkan di jurnal internasional. Untuk itu dilakukan penelitian tentang proses produksi biodiesel menggunakan metanol bekas yang tidak di recovery dan dilakukan secara berulang-ulang yang bertujuan untuk mengamati pengaruh pengunaan metanol bekas terhadap rendemen dan mutu biodiesel yang dihasikan menggunakan reaktor kavitasi hidrodinamik. 


\section{METODOLOGI PENELITIAN}

Bahan yang digunakan pada penelitian ini adalah: minyak kelapa sawit dalam kemasan yang diperoleh dari toko kelontong diseputaran Banda Aceh, katalis $\mathrm{KOH}$, metanol baru dan metanol bekas pakai. Adapun bahan yang digunakan untuk analisis kimia yaitu indikator $\mathrm{pp}, \mathrm{HCl} 0,1 \mathrm{~N}$, metanol 95\%, KI 15\%, KOH 0,1 N, dan bahan-bahan analisis lainnya.

Peralatan yang digunakan adalah satu rangkaian reaktor kavitasi hidrodinamik, alat pemanas, digital thermocontroller, magnetic stirrer, stopwatch, corong pemisah, termometer, dan alat-alat gelas lainnya. Alat yang digunakan untuk analisis adalah timbangan analitik, viscometer, piknometer 5 $\mathrm{ml}$, erlenmeyer, labu ukur $500 \mathrm{ml}$, buret, cawan porselen, dan peralatan gelas lainnya.

\section{Prosedur}

Penelitian dilaksanakan di laboratorium proses Balai Riset dan Standardisasi Industri Banda Aceh. Variabel yang digunakan dalam penelitian ini adalah sebagai berikut: rasio molar metanol dan minyak $4: 1$, konsentrasi katalis $\mathrm{KOH} 1 \%$, temperatur proses $45^{\circ} \mathrm{C}$ dan waktu proses 60 menit dengan jumlah ulangan pemakaian metanol sebanyak 4 ulangan terdiri dari ulangan 1 (metanol baru) dan ulangan 2,3 dan 4 (metanol bekas).

Metanol dan $\mathrm{KOH}$ dimasukkan ke dalam labu ukur dan diaduk selama \pm 15 menit menggunakan magnetic stirrer. Setelah bercampur, larutan dimasukan ke dalam reaktor kavitasi hidrodinamik yang telah berisi minyak yang sebelumnya telah dipanaskan pada suhu $60{ }^{\circ} \mathrm{C}$. Selanjutnya peralatan dihidupkan sehingga reaktan bersirkulasi dan bereaksi sesuai dengan waktu reaksi yang telah ditentukan. Hasil reaksi transesterifikasi dimasukkan ke dalam corong pemisah dan diendapkan selama 2 jam. Di dalam corong pemisah akan terbentuk 2 fase terpisah yaitu biodiesel di lapisan atas dan gliserol di lapisan bawah. Lapisan atas hasil pemisah yang berupa biodiesel, masih mengandung air, alkohol dan sabun sehingga harus dilakukan proses pencucian dengan air hangat $\left(50{ }^{\circ} \mathrm{C}\right)$, kemudian dilakukan proses pemanasan pada suhu $110{ }^{\circ} \mathrm{C}$ untuk menghilangkan air yang kemungkinan masih terikut sehingga dapat diperoleh biodiesel dengan kemurnian tinggi. Metanol sisa transesterifikasi digunakan kembali sebagai pelarut dan diulang-ulang sebanyak 3 kali ulangan.

Produk biodiesel yang dihasilkan selanjutnya dilakukan pengujian yang meliputi uji massa jenis, viskositas kinematik dan bilangan asam, hasil pengujian dibandingkan dengan standar SNI 04-7182 : 2006.

\section{HASIL DAN PEMBAHASAN}

\section{Rendemen Biodiesel}

Salah satu keberhasilan produksi biodiesel ditentukan oleh jumlah molar pelarut terhadap jumlah bahan baku pada proses transesterifikasi. Proses transesterifikasi merupakan reaksi kesetimbangan sehingga diperlukan metanol dalam jumlah tertentu untuk mendorong reaksi ke kanan sehingga dihasilkan rendemen biodiesel yang maksimal. Semakin banyak jumlah metanol yang digunakan maka konversi ester yang dihasilkan akan bertambah banyak, namun pada penambahan metanol yang berlebih dapat menurunkan konversi biodiesel. Penggunaan metanol yang berlebihan dapat menghasilkan bilangan asam yang lebih rendah, namun rendemen biodiesel akan menurun disebabkan terganggunya proses pemisahan gliserol. Metanol yang berlebihan juga akan menyebabkan meningkatnya kelarutan gliserol dalam metanol karena sisa gliserol dalam larutan akan membawa reaksi kesetimbangan ke kiri, sehingga menurunkan rendemen biodiesel (Komintarachat and Chuepeng, 2010). Pada penelitian ini digunakan metanol baru (ulangan 1) dan metanol bekas pakai (ulangan 2, 3 dan 4) dengan jumlah katalis $1 \%$, waktu proses 60 menit dan temperatur proses $45{ }^{\circ} \mathrm{C}$. Hasil penelitian disajikan pada Gambar 1.

Berdasarkan data dari Gambar 1, dapat dilihat bahwa rata-rata rendemen biodiesel tertinggi didapat pada perbandingan molar 4:1 pada berbagai ulangan. Sedangkan 
rendemen biodiesel tertinggi didapat pada ulangan ke 3 pada perbandingan molar 4:1 mencapai $92,36 \%$. Data pada Gambar 1 juga menunjukkan bahwa penggunaan metanol bekas pakai (ulangan 1,2 dan 3) akan menghasilkan rendemen biodiesel lebih tinggi bila dibandingkan dengan penggunaan metanol baru.

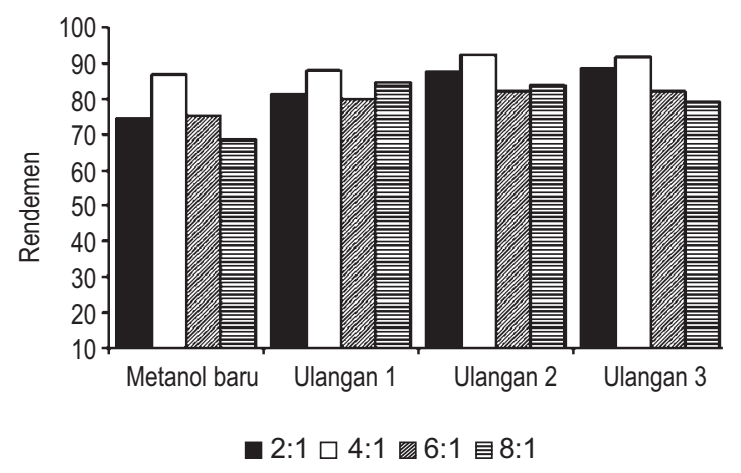

Gambar 1. Pengaruh penggunaan metanol bekas pakai terhadap rendemen biodiesel yang dihasilkan

Dari data pada Gambar 1 juga dapat dilihat bahwa rendemen biodiesel menunjukkan kecenderungan semakin tinggi dengan penggunaan metanol bekas pakai pada berbagai ulangan dan perbandingan molar. Adanya kecendrungan ini diduga salah satunya disebabkan oleh semakin tingginya konsentrasi katalis pada penggunaan metanol bekas pakai karena mentanol bekas pakai (pada ulangan 2, 3 dan 4) merupakan metanol hasil transesterifikasi sebelumnya yang telah mengandung katalis dalam jumlah tertentu. Konsentrasi katalis dapat memberikan efek terhadap rendemen biodiesel. Ketika konsentrasi katalis meningkat maka proses konversi trigliserida dan rendemen biodiesel semakin meningkat. Jika konsentrasi katalis tidak mencukupi akan menyebabkan proses konversi trigliserida di dalam minyak lemak tidak berjalan sempurna. Umumnya, rendemen biodiesel tertinggi didapat pada konsentrasi katalis 1,5\% (Leung et al, 2010). Namun pada penggunaan katalis yang berlebihan akan menurunkan rendemen biodiesel karena terjadinya penyabunan dan kesulitan dalam pemisahan gliserol dan biodiesel. Hal ini dapat dilihat pada perbandingan molar 6:1 dan 8:1 dimana pada berbagai ulangan, rendemen biodiesel semakin rendah.

\section{Viskositas Kinematik}

Viskositas kinematik adalah suatu angka yang menyatakan besarnya hambatan dari suatu bahan cair untuk mengalir atau ukuran dari besarnya tahanan geser dari cairan. Makin tinggi viskositasnya, makin kental dan semakin sukar mengalir. Viskositas kinematik menjadi parameter utama dalam penentuan mutu biodiesel, karena memiliki pengaruh besar terhadap efektifitas biodiesel sebagai bahan bakar. Umunya minyak nabati dan hewani memiliki nilai viskositas jauh di atas viskositas bahan bakar diesel yang dipersyaratkan, hal ini menjadi kendala penggunaan langsung minyak nabati atau hewani sebagai bahan bakar. Salah satu tujuan utama transesterifikasi adalah menurunkan viskositas minyak nabati sehingga memenuhi standar bahan bakar diesel. Sistem pembakaran membutuhkan bahan bakar yang dapat membentuk partikulat halus ketika diinjeksi. Kisaran viskositas kinematik yang ditetapkan dalam standar SNI 04-7182-2006 antara 2,3-6,0 $\mathrm{mm}^{2} / \mathrm{s}$ pada temperatur $40^{\circ} \mathrm{C}$.

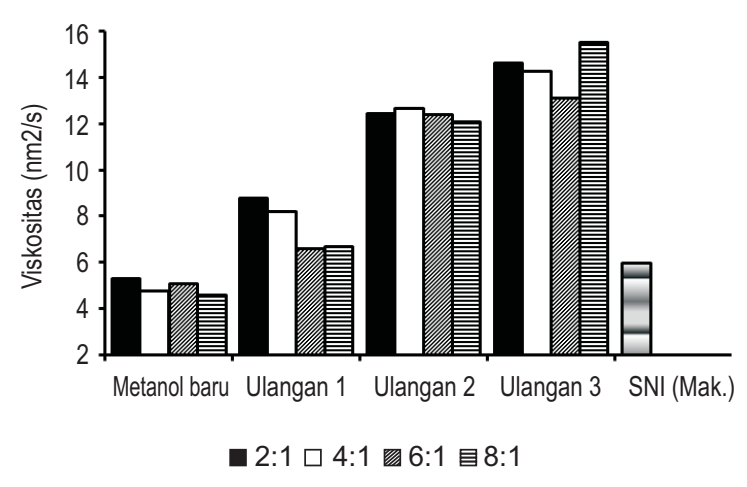

Gambar 2. Pengaruh penggunaan metanol bekas pakai terhadap viskositas kinematik biodiesel

Berdasarkan data pada Gambar 2 dapat dilihat bahwa penggunaan metanol bekas pakai pada berbagai ulangan akan 
menghasilkan nilai viskositas yang semakin tinggi melebihi dari ambang batas SNI yaitu maksimum $6,0 \mathrm{~mm}^{2} / \mathrm{s}$. Tingginya viskositas kinematik pada penggunaan metanol bekas pakai menandakan reaksi pembentukan metil ester tidak berjalan dengan tuntas. Jika reaksi tidak berjalan dengan tuntas, akan terdapat banyak trigliserida yang tidak diubah menjadi metil ester. Keadaan ini berdampak pada tingginya nilai viskositas kinematik, karena trigliserida lebih kental dari metil ester. Oleh karena itu viskositas kinematik sekaligus mengindikasikan kesempurnaan reaksi transesterifikasi (Sari, 2007). Jika viskositas bahan bakar terlalu rendah, akan menyebabkan kebocoran yang mengurangi daya pembakaran, jika viskositas terlalu tinggi, bahan bakar akan sulit disuplai ke ruang pembakaran, hal ini juga menyebabkan berkurangnya daya pembakaran (Gerpen et al, 2004). Viskositas yang tinggi juga akan menyebabkan masalah pada cuaca dingin, karena viskositas akan semakin tinggi seiring dengan penurunan suhu sehingga sistem injeksi bahan bakar akan tersumbat (Joshi and Pegg, 2007).

\section{Densitas}

Densitas adalah massa minyak per satuan volum pada suhu tertentu. Densitas merupakan salah satu kunci keberhasilan produksi biodiesel yang akan mempengaruhi kinerja mesin. Beberapa karakteristik biodiesel seperti angka setana (cetane number) dan nilai bakar (heating value) berhubungan dengan densitas (Tat and Gerpen, 2000). Kisaran nilai densitas yang ditetapkan dalam standar SNI 04-7182-2006 antara $850-890 \mathrm{~kg} / \mathrm{m}^{3}$ pada temperatur $40{ }^{\circ} \mathrm{C}$. Gambar 3 menyajikan nilai densitas biodiesel yang dihasilkan menggunakan metanol baru dan metanol bekas pakai pada berbagai perbadingan molar.

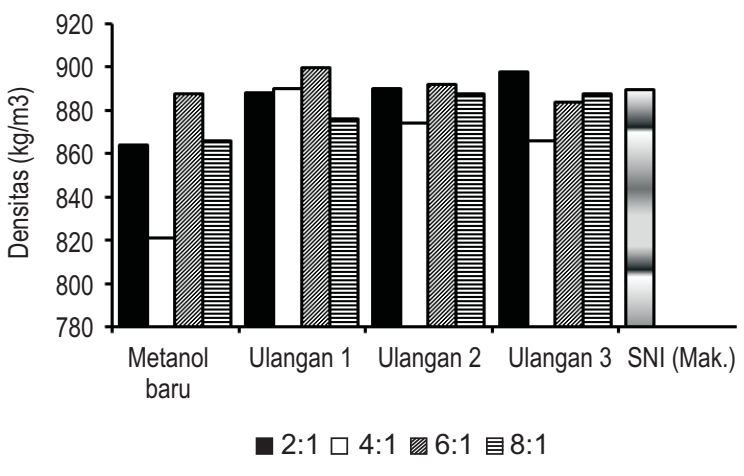

Gambar 3. Pengaruh penggunaan metanol bekas pakai terhadap nilai densitas biodiesel

Berdasarkan data pada Gambar 3 dapat dilihat bahwa penggunaan metanol bekas pakai pada berbagai ulangan secara umum menghasilkan nilai densitas antara $821-890 \mathrm{~kg} / \mathrm{m}^{3}$, nilai densitas ini masih memenuhi persyaratan SNI. Namun pada ulangan ke 3 pada perbandingan molar 2:1 dan ulangan 1 dan 2 pada perbandingan molar 6:1 menghasilkan nilai densitas diatas persyaratan SNI mencapai $892-900 \mathrm{~kg} / \mathrm{m}^{3}$. Densitas bahan bakar biodiesel memberikan efek pada volume bahan bakar yang diinjeksikan kedalam ruang bakar dan mempengaruhi rasio pencampuran bahan bakar dan udara. Umumnya pompa injeksi menghitung jumlah bahan bakar berdasarkan volume bukan massa dan kepadatan bahan bakar akan menghasilkan massa yang lebih besar pada volume yang sama. Karena itu, perubahan densitas akan mempengaruhi output tenaga mesin karena perbedaan massa dari injeksi bahan bakar (Aptekin and Canacki, 2008).

\section{Bilangan Asam}

Adanya bilangan asam dalam biodiesel tergantung dari beberapa vaktor, misalnya dipengaruhi oleh jenis bahan baku yang digunakan untuk memproduksi biodiesel. Angka asam yang tinggi merupakan indikator biodiesel masih mengandung 
asam lemak bebas yang akan menyebabkan korosi pada mesin dan akan membentuk deposit dalam ruang pembakaran serta menyebabkan penyumbatan injektor (Refaat, 2009). Kisaran bilangan asam yang ditetapkan dalam standar SNI 04-7182-2006 yaitu maksimum $0,8 \mathrm{mg}-\mathrm{KOH} / \mathrm{g}$. Gambar 4 menyajikan nilai bilangan asam biodiesel yang dihasilkan menggunakan metanol baru dan metanol bekas pakai pada berbagai perbadingan molar.

Dari data pada Tabel 4 diatas juga dapat dilihat bahwa penggunaan metanol baru dan metanol bekas pakai menghasilkan nilai bilangan asam antara 0,35 - 0,54 mg$\mathrm{KOH} / \mathrm{gr}$ dan masih memenuhi persyaratan $\mathrm{SNI}$ yaitu maksimum 0,80 mg-KOH/gr.

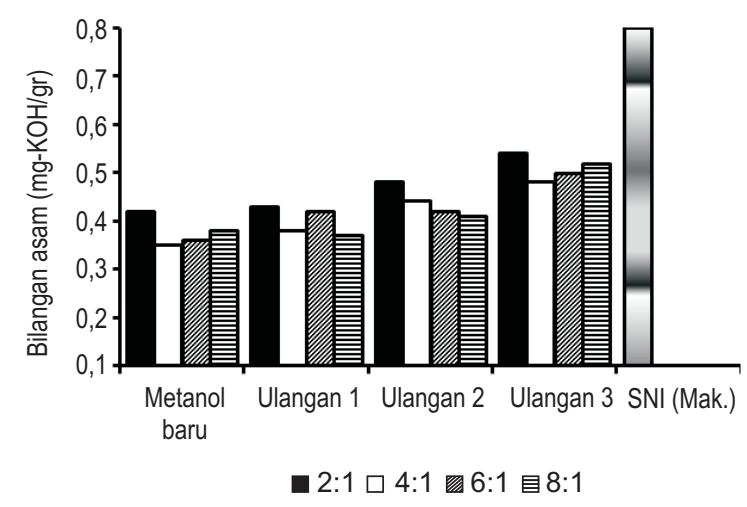

Gambar 4. Pengaruh penggunaan metanol bekas pakai terhadap bilangan asam biodiesel

Kandungan bilangan asam dalam biodiesel meramalkan tingkat kerusakan metil ester selama penyimpanan beberapa waktu ke depan. Tingkat oksidasi tinggi juga menandakan biodiesel tidak tahan lama disimpan, sebab senyawa peroksida yang menjadi produk intermediet pada reaksi oksidasi dapat menyerang asam lemak lainnya yang masih utuh, sehingga akan terbentuk asam lemak bebas rantai pendek yang lebih banyak. Nilai bilangan asam juga menjadi indikator kerusakan yang terjadi pada biodiesel. Hal ini disebabkan peningkatan bilangan asam seperti halnya peningkatan viskositas dan bilangan peroksida adalah hasil aktifitas oksidasi pada biodiesel (Canacki., Gerpen, 1999). Oleh karena itu, jika bilangan asam metil ester tinggi, berarti telah terjadi kerusakan akibat oksidasi.

\section{KESIMPULAN}

Penggunaan metanol bekas pakai secara berulang-ulang menggunakan reaktor kavitasi hidrodinamik dapat menghasilkan biodiesel dengan rendemen antara $79,2 \%$ hingga $92,36 \%$ dengan karakteristik biodiesel yang dihasilkan adalah: nilai viskositas antara 6,72 - 15,53 $\mathrm{mm}^{2} / \mathrm{s}$, densitas antara $876-900 \mathrm{~kg} / \mathrm{m}^{3}$ dan bilangan asam $0,37-0,54 \mathrm{mg}-\mathrm{KOH} / \mathrm{gr}$. Berdasarkan data diatas dapat disimpulkan bahwa produk biodiesel yang dihasilkan belum dapat digunakan secara langsung di mesin diesel karena beberapa parameter uji belum memenuhi persyaratan SNI 04-71822006.

\section{DAFTAR PUSTAKA}

Aptekin, E and Canacki M. 2008. Determination of the density and the viscosities of biodiesel-diesel fuel blends. Renew. Energy, 33: pp.26232630.

Canakci and Gerpen. 2001. Biodiesel production from oils and fat with high free fatty acid. Transaction of the American Society of Agricultural Engineers, 44: pp. 1429-1436.

Canacki, M. and Gerpen V. 1999. Biodiesel Production Via Acid Catalysis. Trans ASAE, 42: pp.1203-1210.

Dhar R.B and Kirtania K. 2009. Excess methanol recovery in biodiesel production process using a distillation column: A mimulation study. Chemical Engineering Research Bulletin, 13: pp. 55-60. 
Gerpen JKG and Knothe. 2005. The Biodiesel Handbook. AOCS Pres.

Gerpen, J.V., Shanks, B., Pruszko, R., Clements, D., and Knothe, G. 2004. Biodiesel Analytical Methods. NREL/SR-51036240. Juli 24 (Online), http://www.nrel.gov.

Hambali, E., Suryani, A., Dadang., Hariyadi., Hanafie, H., Reksowardojo, I.K., Rivai, M., Ihsanur, M., Suryadarma, P., Tjitrosemito, S., Sorawidjaja, T.H., Prawitasari, T., Prakoso, T., Purnama W. 2006. Jarak Pagar Tanaman Penghasil Biodiesel. Penerbit Penebar Swadaya, Jakarta.

Ji, J., Wang, J., Li, Y., Yu, Y., and Xu, Z. 2006. Preparation of biodiesel with the help of ultrasonic and hydrodinamik cavitation. Ultrasonic, 44: pp. 411-414.

Joshi, R.M., Pegg, M.J. 2007. Flow properties of biodiesel fuel blends at low temperatures. Fuel, 87: pp. 143151.

Kelkar, M.A., Gogate, P.R., Pandit, A.B. 2008. Intensification of esterification of acid for synthesis of biodiesel using acoustic and hydrodinamik cavitation. Ultrasonics Sonochemistry,15: pp. 180-188.

Komintarachat, C and Chuepeng, S. 2010. Metanol Based Transesterification Optimization of Waste Used Cooking Oil Over Potassium Hydroxide Catalyst. American Journal of Applied Science, 8: pp. $184-188$

Lee, S.B., Lee, J.D., Hong, I.K. 2011. Ultrasonic energy effect on vegetable oil based biodiesel synthetic process. Journal of Ind. Eng. Chem, 17: pp. 138143.
Leung, D.Y.C., Wu X., and Leung M.K.H. 2010. A review on biodiesel production using catalyzed transesterification. Applied Energy, 87: pp. 1083-1095.

Ma, F and Hanna, M.A. 1999. Biodiesel Production: a Review. Journal of Bioresource Technology 70, USA.

Moholkar, V.S., Senthil Kumar, P., and Pandit A.B. 1999. Hydrodinamic cavitation for sonochemical effects. Ultrasonic Sonochemistry, 6: pp. 5365.

Refaat, A.A. 2009. Correlation between the chemical structure of biodiesel and its physical properties. Int. J. Environ. Sci. Tech, 4: pp.677-694.

Sahirman., Suryani A., Mangunjidjaja D., Sukardi., Sudrajat R, 2008. Pengujian Sifat Fisiko-Kimia, Kinerja dan Pengaruh Pada Mesin Terhadap Biodiesel Dari Minyak Biji Bintagur (Cailophylum inopylum). Prosiding Seminar Nasional Hasil Penelitian, Bogor. pp. 84-97.

Sari, T.B.A. 2007. Proses pembuatan biodiesel minyak jarak pagar (Jatropha curcas L.) dengan transesterifikasi satu dan dua tahap. Skripsi. Departemen Teknologi Industri Pertanian, Fakultas Teknologi Pertanian, Institut Pertanian Bogor.

Tat, M.E and Gerpen V.J.H. 2000. The spesific gravity of biodiesel and its blends with diesel fuel. J. Am. Oil Chem. Soc, 77: pp.115-119. 